\title{
Comparative Study of Attenuation of effects of Intubation on Blood Pressure Using IV Xylocard and IV Beta Blocker (Esmolol)
}

\author{
Mirza Afzal Baig ${ }^{1}$ \\ ${ }^{1}$ Department of Anaesthesiology, KBNIMS, Kalaburagi, Karnataka.
}

\section{Abstract}

Background: The occurrence of cardio vascular reactions to laryngoscopy and tracheal intubation has attracted the attention of anaesthesiologists and methods to avoid these potentially harmful responses even though transitory have been sought, particularly in critically ill patients, hypertensive patients. Tracheal intubation under light general anaesthesia is consistently accompanied by a pressor response, tachycardia and in some instances by cardiac arrhythmias. This pressor response, which was recognised early as 1951 is due to sympathetic reflex provoked by stimulation of the epipharynx and laryngopharynx. Subjects and Methods: Seventy five (75) patients belonging to ASA grade $1 \& 2$ scheduled for general surgical, orthopaedic surgical, ENT, gynocological surgical producers were studied. Results: The age of the patients varied from 10 to 60 years. The MAP in group A decreased after induction. There was a highly significant raise to $109+/-11 \mathrm{~mm} \mathrm{Hg}$ during laryngoscopy and intubation. This decreased to $105+/-9 \mathrm{~mm} \mathrm{Hg}$ after five minutes which is not significant. Conclusion: These responses are transitory, variable and are much more marked in a hypertensive patient than in the normotensive patient. Once the laryngoscopy and endotracheal intubation is completed, the increase in pulse and blood pressure subside, but the dysrhythmia persists for more than 2-3 minutes.

Keywords: Intubation, Blood Pressure, Xylocard and IV Beta blocker

Corresponding Author: Dr. Mirza Afzal Baig, Department of Anaesthesiology, KBNIMS, Kalaburagi, Karnataka.

Received: May 2019

Accepted: June 2019

\section{Introduction}

Induction of anaesthesia is recognised as a hazardous phase in the management of the patient during the operative procedure. The occurrence of cardio vascular reactions to laryngoscopy and tracheal intubation has attracted the attention of anaesthesiologists and methods to avoid these potentially harmful responses even though transitory have been sought, particularly in critically ill patients, hypertensive patients. Tracheal intubation under light general anaesthesia is consistently accompanied by a pressor response, tachycardia and in some instances by cardiac arrhythmias. ${ }^{[1]}$ This pressor response, which was recognised early as 1951 is due to sympathetic reflex provoked by stimulation of the epipharynx and laryngopharynx. This is hazardous to those with hypertension, myocardial or cerebrovascular insufficiency in whom subarchnoid haemorrhage, myocardial ischemia, left ventricular failure or cardiac arrhythmias can occur. Several techniques have been used with varying degrees of success to obtund this pressor response to laryngoscopy and tracheal intubation. Including intravenous or topical lignocaine, thoracic epidural analgesia, by deepening general anaesthesia, intravenous opiods, alpha and beta adrenergic receptor blocker, and peripheral vasodilators. ${ }^{[2]}$ But none of the pharmacological approaches has proved entirely satisfactory, as the reflex is not completely blocked. The agents used to block the response may themselves produce undesirable side effect. As stretching of the tissues of the epipharynx and laryngopharynx presumably trigger the reflex response, minimising stretching of tissues as during blind nasal intubation sounds more theoretical. ${ }^{[3,4]}$

The aim of the present study was to observe the occurrence of any increase in Blood Pressure, increase in Heart rate and / or cardiac arrhythmias during laryngoscopy and tracheal intubation. An attempt was made to minimise these responses by either intravenous $2 \%$ lignocaine hydrochloride (in dose of $1.5 \mathrm{mg} \mathrm{Kg}-1$ body weight) because of its well established central depressant and antiarrhythmic effects or with intravenous esmolol hydrochloride (in a dose of 500 $\mathrm{mcg} / \mathrm{Kg}$ body weight) which is a relatively new cardio selective intravenous beta blocker which has rapid onest of action exerts a peak hemodynamic effects within minutes and has a short elimination half life of $9.2 \mathrm{~min}$, consequently it should prove ideal for control of the short lived haemodyamic sequele associated with laryngoscopy and tracheal intubation.

\section{Subjects and Methods}

Seventy five (75) patients belonging to ASA grade $1 \& 2$ scheduled for general surgical, orthopaedic surgical, ENT, gynocological surgical producers were studied. The age of the patients varied from 10 to 60 years. 
0

\section{Pre Anaesthetic Assesment}

Pre anaesthetic assessment was done on the day prior to surgery. The patients are posted for surgery for general surgical, orhpaedic, gynaecological, ENT problems. They had no associated diseases.

A routine pre-anaesthetic examination was conducted assessing:-

1. General condition of the patient

2. Nutritional status and weight of the patient.

3. A detailed examination of the cardio vascular system including recording of blood pressure.

4. An examination of the respiratory system.

5. Other associated diseases.

The following investigations were done:-

1. Routine Haemogram, including Haemoglobin estimation, total count, differential count, ESR.

2. Urine examination: Albumin, Sugar, and Microscopic Examination.

3. Blood sugar (Random)

4. Blood urea and serum creatinine

5. Electro cardiogram (EKG) and Chest X-ray was done in patients over 40 year of age and those patients who had cardiovascular and respiratory problems.

\section{Premedication:-}

All the patients included in the study were given anxiolytics Alprazolom $2.5 \mathrm{mg}$ orally on the previous night of the surgery. Thirty minutes Before induction each patient received pethedine $1-2 \mathrm{mg} / \mathrm{kg}$ and promethazine $1 \mathrm{mg} / \mathrm{kg}$ intramuscularly.

\section{Procedure}

The patients were studied in groups A,B, and C.

Group "A" Patients served as control.

Group "B" in this group patients received intra-venous xylocard $1.5 \mathrm{mg} / \mathrm{kg}$

Group "C" - This group received intravenous esmolol hydrochloride $500 \mathrm{mcg} \mathrm{kg}-1$.

\section{Technique:-}

All the patients in the groups A,B and C were induced with thiopentone sodium $5 \mathrm{mg} \mathrm{kg}-1$ and succinylcholine $1.5 \mathrm{mg}$ $\mathrm{kg}-1$. All the patients were pre-oxygenated for 3 minutes before induction.

In group A, laryngoscopy was performed after the fasciculation's subsided using Macintosh laryngoscope and intubation performed with a suitable endotracheal tube, anaesthesia was the maintained with $60 \%$ Nitrous oxide and $40 \%$ oxygen.

In group B, laryngoscopy was performed after one minute of administering intravenous xylocard $1.5 \mathrm{mg} / \mathrm{kg}$. Xylocard was administered immediately after succinylcholine injected. Anaesthesia was then maintained with $60 \%$ Nitrous oxide ad $40 \%$ oxygen.

In group $\mathrm{C}$, laryngoscopy and intubation was performed after three minutes of administering intravenous esmolol hydrochloride $500 \mathrm{mcg} \mathrm{kg}-1$. Esmolol hydrochloride was given just after injection of Thiopentoe sodium anaesthesia was maintained with $60 \%$ Nitrous oxide and $40 \$$ oxygen.

In all the three groups $0.5 \%$ Halothane was started just after intubation to prevet the patients from becoming lighter.

Results

In the present series seventy five patients hospitalised for undergoing various surgical procedures were selected for the attenuation of hemodynamic changes during laryngoscopy and oro-endotracheal intubation.

\section{Table 1: Gender Distribution}

\begin{tabular}{|l|l|l|l|l|}
\hline Groups & $\begin{array}{l}\text { Agents For } \\
\text { Attenuation }\end{array}$ & $\begin{array}{l}\text { No.Of } \\
\text { Patients }\end{array}$ & Male & Female \\
\hline $\mathrm{A}$ & Control & 25 & 12 & 13 \\
\hline $\mathrm{B}$ & $\begin{array}{l}\text { IV Xylocard 1.5 } \\
\mathrm{mg} / \mathrm{kg}\end{array}$ & 25 & 15 & 10 \\
\hline $\mathrm{C}$ & $\begin{array}{l}\text { IV Esmolol HCL } \\
500 \mathrm{mcg} / \mathrm{kg}\end{array}$ & 25 & 16 & 09 \\
\hline Total & 75 & 43 & 32 \\
\hline
\end{tabular}

As seen in [Table 1], of the 75 patients $43(57.3 \%)$ were males and $32(42.65 \%)$ were females. In Group "A" there were $12(48 \%)$ Males and $13(52 \%)$ females. Group "B" had $15(60 \%)$ Males and 10(40\%) Females. While group "C" had $16(54 \%)$ males and 9(36\%) Females.

\section{Table 2: The age distribution.}

\begin{tabular}{|l|l|l|l|l|l|}
\hline $\begin{array}{l}\text { Age In } \\
\text { Years }\end{array}$ & $\mathbf{A}$ & $\mathbf{B}$ & $\mathbf{C}$ & Total & \% \\
\hline $11-20$ & 4 & 5 & 2 & 11 & $14.64 \%$ \\
\hline $21-30$ & 9 & 7 & 8 & 24 & $32 \%$ \\
\hline $31-40$ & 6 & 5 & 4 & 15 & $20 \%$ \\
\hline $41-50$ & 4 & 4 & 7 & 15 & $20 \%$ \\
\hline $51-60$ & 2 & 4 & 4 & 10 & $13.36 \%$ \\
\hline Total & 25 & 25 & 25 & 75 & $100 \%$ \\
\hline
\end{tabular}

The youngest patient included in this study was 11 years boy, oldest was fifty nine (59) years. Most of the patients i.e. $72 \%$ belonged to the age group 11-20 years while $14.64 \%$ belong to age group 11 to 20 years while only $13.36 \%$ were above 50 years.

Table 3: The systolic B.P. during various time intervals

\begin{tabular}{|l|l|l|l|}
\hline Timing & A & B & C \\
\hline Basal & $119+/-12$ & $127+/-15$ & $124+/-12$ \\
\hline Preinduction & $116+/-9$ & $122+/-13$ & $124+/-12$ \\
\hline Just Before Laryngoscopy & $102+/-10$ & $108+/-21$ & $109+/-13$ \\
\hline Laryngoscopy + ETI & $149+/-19$ & $144+/-22$ & $129+/-20$ \\
\hline 1st minute after ETI & $146+/-16$ & $140+/-21$ & $126+/-19$ \\
\hline 2nd minute after ETI & $143+/-16$ & $133+/-18$ & $122+/-18$ \\
\hline 5th minute after ETI & $142+/ 16$ & $132+/-19$ & $120+/-20$ \\
\hline
\end{tabular}

Table 4: Systolic BP before induction and after induction and intubation

\begin{tabular}{|l|l|l|l|}
\hline Sl. No & A & B & C \\
\hline Just Before Laryncoscopy & -14 & -14 & -15 \\
P & $>0.05$ & $>0.05$ & $>0.5$ \\
Remarks & NS & NS & NS \\
\hline Laryncoscopy + ETI & +33 & +36 & +5 \\
P & $<0.001$ & $<0.001$ & $<0.005$ \\
Remarks & VHS & VHS & NS \\
\hline
\end{tabular}

Table 5: A comparison between the systolic BP at intubation and five minutes

\begin{tabular}{|l|l|l|l|}
\hline & and five minutes & B & C \\
\hline Mean Of The Difference & $-7+/-5$ & $-14+/-6$ & $-9+/-9$ \\
$\mathrm{P}$ & $>0.05$ & $<0.001$ & $<0.001$ \\
Remarks & NS & VHS & VHS \\
\hline
\end{tabular}


0

In group $A$ the systolic pressure decreased from a preinduction value of $116+/-9$ to $102+/-10$. This was followed by an increase to $149+/-17$ following intubation which is highly significant. There was no significant decrease in $\mathrm{BP}$ at the end of the five minutes $(\mathrm{P}>0.005)$.

In group $\mathrm{B}$, the decrease in systolic blood pressure following induction was $14 \mathrm{~mm} \mathrm{Hg}$. There is no significant increase during laryngoscopy and ETI. The fall in BP at the end of five minutes following intubation was highly significant $(\mathrm{P}<0.001)$.

The fall in systolic blood pressure in group $\mathrm{C}$ following induction was $15 \mathrm{~mm} \mathrm{Hg}$. The increase in blood pressure from the induction level was $20 \mathrm{~mm} \mathrm{Hg}$, at the time of laryngoscopy, which was highly significant. At the end of five minutes the blood pressure decreased by an average of 9 $\mathrm{mm} \mathrm{Hg}$ which is once again statistically highly significant $(\mathrm{P}<0.001)$

\section{Table 6: Mean arterial Pressure}

\begin{tabular}{|l|l|l|l|}
\hline Timing & A & B & C \\
\hline Basal & $94+/-6$ & $96+/-7$ & $95+/-6$ \\
\hline Preinduction & $92+/-4$ & $95+/-8$ & $96+/-5$ \\
\hline Just before laryngoscopy & $86+/-6$ & $87+/-10$ & $89+/-6$ \\
\hline Laryngoscopy + ETI & $109+/-11$ & $106+/-13$ & $97+/-10$ \\
\hline 1st minute after ETI & $107+/-11$ & $103+/-13$ & $95+/-10$ \\
\hline 2nd minute after ETI & $105+/-9$ & $99+/-10$ & $93+/-11$ \\
\hline 5th minute after ETI & $105+/-9$ & $98+/-10$ & $93+/-10$ \\
\hline
\end{tabular}

Table 7: The changes in MAP following induction and intubation as compared to pre induction values

\begin{tabular}{|l|l|l|l|}
\hline Sl. No & A & B & C \\
\hline Just Before Laryncoscopy & -6 & -8 & -7 \\
P & $>0.05$ & $>0.05$ & $>0.5$ \\
Remarks & NS & NS & NS \\
\hline Laryncoscopy + ETI & +17 & +11 & +1 \\
P & $<0.001$ & $<0.001$ & $>0.05$ \\
Remarks & VHS & VHS & NS \\
\hline
\end{tabular}

Table 8: The increase in MAP at intubation as compared to that following induction

\begin{tabular}{|l|l|l|l|}
\hline & A & B & C \\
\hline Increase IN mm Hg & +23 & +19 & +8 \\
$\mathrm{P}$ & $<0.001$ & $<0.001$ & $<0.001$ \\
Remarks & VHS & VHS & VHS \\
\hline
\end{tabular}

Table 9: The decrease in MAP after five minutes of intubation as compared to that following endotracheal intubation

\begin{tabular}{|l|l|l|l|}
\hline & A & B & C \\
\hline Mean of the Difference & $-4+/-5$ & $-8+/-6$ & $-4+/-4$ \\
$\mathrm{P}$ & $>0.05$ & $<0.001$ & $<0.01$ \\
Remarks & NS & VHS & NS \\
\hline
\end{tabular}

The MAP in group A decreased after induction. There was a highly significant raise to $109+/-11 \mathrm{~mm} \mathrm{Hg}$ during laryngoscopy and intubation. This decreased to $105+/-9 \mathrm{~mm}$ $\mathrm{Hg}$ after five minutes which is not significant.

In Group B a'fall in MAP, similar to that of group A occurred on induction. The MAP rose to $106+/-12 \mathrm{~mm} \mathrm{Hg}$ at laryngoscopy which is highly significant. At the end of five minutes the MAP was $98+/-10 \mathrm{~mm} \mathrm{Hg}$. This decrease is statistically very highly significant. In group C MAP decreased from $96+/ 5 \mathrm{~mm} \mathrm{Hg}$ (preinduction) to $89+/-6 \mathrm{~mm}$ $\mathrm{Hg}$ at induction. This increased to $97+/-10 \mathrm{~mm} \mathrm{Hg}$ following intubation, a significant change. The MAP decreased significantly to level of $93+/-10$ after five minutes.
Table 10: The variations in RPP at various time intervals

\begin{tabular}{|l|l|l|l|}
\hline Timing & A & B & C \\
\hline Basal & $9720+/-$ & $10799+/-$ & $10675+/-$ \\
& 2480 & 2068 & 2119 \\
\hline Preinduction & $9953+/-$ & $11414+/-$ & $11972+/-$ \\
& 1477 & 2063 & 2468 \\
\hline Just before laryngoscopy & $9426+/-$ & $10608+/-$ & $10643+/-$ \\
& 1634 & 2313 & 1894 \\
\hline LARYNGOSCOPY + ETI & $1590+/-$ & $15719+/-$ & $14131+/-$ \\
& 2744 & 2599 & 4196 \\
\hline 1ST MINUTE AFTER ETI & $15443+/-$ & $14784+/-$ & $13524+/-$ \\
& 2476 & 2639 & 4114 \\
\hline 2ND MINUTE AFTER ETI & $14645+/-$ & $13329+/-$ & $12704+/-$ \\
& 2204 & 2255 & 3774 \\
\hline 5TH MINUTE AFTER ETI & $14122+/-$ & $12838+/-$ & $12061+/-$ \\
& 2335 & 2382 & 3891 \\
\hline
\end{tabular}

Table 11: The changes in RPP occurring at induction and endotracheal intubation

\begin{tabular}{|l|l|l|l|}
\hline Sl. No & A & B & C \\
\hline Just Before Laryncoscopy & -527 & -806 & -1329 \\
P & $>0.05$ & $>0.05$ & $>0.5$ \\
Remarks & NS & NS & NS \\
\hline Laryncoscopy + ETI & +5957 & +4305 & +2157 \\
P & $<0.001$ & $<0.001$ & $>0.05$ \\
Remarks & VHS & VHS & NS \\
\hline
\end{tabular}

Table 12: the increase in RPP following intubation when compared to RPP following induction

\begin{tabular}{|l|l|l|l|}
\hline & A & B & C \\
\hline Increase in $\mathrm{mm} \mathrm{Hg}$ & +6484 & +5111 & +3488 \\
$\mathrm{P}$ & $<0.001$ & $<0.001$ & $<0.001$ \\
Remarks & VHS & VHS & VHS \\
\hline
\end{tabular}

\section{Discussion}

The haemodynamic responses to laryngeal and tracheal stimulation in anaesthetised human are tachycardia, a rise in blood pressure and arrhythmias. These facts are derived from studies during different forms of anaesthesia (Raid and Brace - 1940, king Harris and Griefenstin 1950, Noda and Higachi 1964) and are interpreted as a result of reflex sympathoadrenal stimulation. ${ }^{[5]}$

These responses are transitory, variable and are much more marked in a hypertensive patient than in the normotensive patient. Once the laryngoscopy and endotracheal intubation is completed, the increase in pulse and blood pressure subside, but the dysrhythmia persists for more than 2-3 minutes.

The sympathoadrenal response may be hazardous as it compromises the ventricular performance (Giles R.W.1982) lead to myocardial ischemia, pulmonary oedema, cerebral haemorrhage (Fox E.J. 1977) and ventricular arrhythmias (Pry-Roberts, 1971). The complications are more likely in the presence of coronary artery disease 9Larence W Roy 1979). Cerebral atheroma or hypertension (Prys-Roberts, 1971). ${ }^{[6]}$

The other factors contributing to the presser response are (a) anxiety, (b) Atropine premedication (c) Reflex baroreceptor effect upon fall in the arterial pressure after induction with Thiopentone (d) Hypoxia $€$ Hypercarbia and (f) Cough.

Attempts to attenuate the presser response have been made using various approaches. The response may be diminished or modified locally, centrally or peripherally. Different workers have used various modes of attenuation, like topical 
0

anaesthesia of phrynx and larynx (Wycoff,C,C-1960 ShujiDohi - 1982) i.v. lignocaine (Stoeliting R.K - 1978, Abou-Madi-1977). Adrenergic blocking drugs (Mikawa K. 1990), deep general anaesthesia (king B.D. - 1951, Paul R.Knight 1980) vasodilators 9Stoelting R.K. 1979), and nondepolarizing muscle relaxants (Singhal - 1989). ${ }^{[7]}$

The present study was done to measure the cardiovascular response to laryngotracheal stimulation and to find a simple, safe and effective method for diminishing the cardiovascular reaction.

In our study we used IV lignocaine and IV esmolol to attenceate the response. Lignocaine was used in dose of 1.5 $\mathrm{mg} / \mathrm{kg}$ body weight and Esmolol $500 \mathrm{mcg} / \mathrm{Kg}$. Bromage (1961) reports that the concentration of lignocaine will rise to $10 \mathrm{mcg} / \mathrm{ml}$ when $6 \mathrm{mg} / \mathrm{kg}$ given to patient. In man toxic effect occur in conscious subjects at a plasma level of 5 $\mathrm{mcg} / \mathrm{ml}$ and in anaesthetised patients at $10 \mathrm{mceg} / \mathrm{ml}$ when circulatory depression become obvious. In our study, the dose of lignocaine used was therefore considered to be within safe limits. No untoward toxic response occurred in any case in dosage used. Regarding Esmolol toxicity occurred at the dosage of $5000-6250 \mathrm{mg} / \mathrm{kg} / \mathrm{min}$. over $1-2$ min infusion resulted in Brady cardia, Hypotension, loss of consciousness. In our study dosage is too less to cause any toxic untoward responses. Promethazine and ephedrine was used since they reduced the anaesthetic requirements (Miller. A Forber1970 ) and sedtivelypnotic and analgesics. They are not known to attenuate or augment the hemodynamic response to laryngoscopy (Devault 1960) Atropine was totally avoided in our study. ${ }^{[8]}$

Murthy S, James D, Laddu (1986) observed after intubation the peak RPP was lowered in esmolol group than controls, As the RPP is a reliable indicator of Myocardial oxygen demand, attenuation of intubation induced increase in RPP with esmolol supports the cardio protective effect of such treatment.

Mean arterial pressure changes in our study was similar to that of systolic blood pressure. It increased from awake levels by $17 \mathrm{~mm} \mathrm{Hg}$, in group A and by 11 and $1 \mathrm{~mm} \mathrm{Hg}$, in group $\mathrm{B}$ and $\mathrm{C}$ respectively following intubation. Curran.J.(1980) reported that MAP increased to $26.5 \mathrm{~mm} \mathrm{Hg}$ in response to intubation in their control group. James F.Hamill (1981) observed that I.V. esmolol $500 \mathrm{mcg} / \mathrm{kg}$ is more effective that IV lignocaine $1.5 \mathrm{mg} / \mathrm{kg}$ in reducing the MAP raise following intubation. Thus observations in our study compares with those of James F.Hamill. ${ }^{[9]}$

The Rate Pressure Product (RPP) correlates with myocardial oxygen consumption and bears fairly constant relationship to the onset of angina pectoris in any patient with ischemic heart disease. If the RPP for the development of angina or ischaemic chages in the E.C.G is known for a particular patient, the anaestheisiologist should maintain a lower R.P.P during the perioperative period. In the absence of specific information it is desirable to keep the R.P.P. at less than 15,000 .

Lawrence Roy et al. (1979) noted that R.P.P in excess of 11,000 in patients with coronary artery disease was associated with $38 \%$ incidence of myocardial ishaemia. Bedford (1980) had got peak R.P.P values of 20,792+/-871 in mildly hypertensive patients. In our study the peak mean R.P.P was $15910+/-2744,157129+/-2599,14131+/-4196$ in group A,B and C respectively. Also the R.P.P returned to basal levels by 5 minutes in group $C$ while it was nearly so in group B. In group A, R.P.P remained persistently high even after 5 minutes. Therefore the values suggest that there was a Better attenuation in Group $\mathrm{C}$ when compared to B. Our values are comparable to other techniques used. The R.P.P of $13286 \mathrm{~mm} \mathrm{Hg}$. Beat/min with triemthaphan (N.Saitoh 1991), $17916 \mathrm{~mm} \mathrm{Hg}$. Beat $/ \mathrm{mm}$ with hydrallazine and 15868 $\mathrm{mm} \mathrm{Hg}$. Beat/min with buprenorphine, $11914 \mathrm{~mm} \mathrm{Hg}$. Beats/min with dilitiazem (K.Mikawa - 1990) and over $11000 \mathrm{~mm} \mathrm{Hg}$. Beats/min with labetalol (Fishler.M - 1985). The effect of endotracheal intubation on ECG was reported by Reid and Breace (1940). They suggested that the changes are reflex in origin. In our study all the 75 patients developed sinus tachycardia following induction and endortracheal intubation. Though the R.P.P in all the groups exceeded $14,000 \mathrm{~mm} \mathrm{Hg}$ beat $/ \mathrm{min}$, no S-T segment or $\mathrm{T}$ wave changes were observed.

Burstien (1951) reported ECG changes in 68\% of cases. They reported ST-T depression after large doses 0of thiopentone and was considered to be due to direct myocardial depression or reducedcoronary blood flow. They suggested that insufficient depth of anaesthesia, prolonged laryngoscopy, numerous attempts at intubation, respiratory obstruction before intubation leading to accumulation of $\mathrm{CO} 2$ of tracheal irritation have been suggested as cause for arrhythmias. ${ }^{[8]}$

Abou-Maid (1977) reports that a blood concentration of above $2 \mathrm{micro}$ gram $/ \mathrm{ml}$ are required for an antiarrhythmic effect. Stoelting (1977) observed blood level of 2 microgram / $\mathrm{ml}$ after a lignocaine spray of $2 \mathrm{mg} / \mathrm{kg}$ body weight. Therefore a direct myocardial depression in patients receiving a spray of $4 \%$ lignocaine in the dose of $2 \mathrm{mg} / \mathrm{kg}$ body weight is unlikely. Oscar Viegas (1975) also concluded that a plasma concentration of 2-5 m8icrogram / $\mathrm{ml}$ of lignocaine is necessary for antiarrhythmic effect.

Nair G.L. (1985) reported that miaximum incidence of arrhythmias occurred in the thiopentone - relaxant technique which decreased by deepening the plane of anaesthesia using ether. Sharma U.C.(1984) reported that the commonest E.C.G finding following endortracheal intubation is tachycardia, which is comparable to our study. Haranth K.Baba (1974) opined That the E.C.G changes observed at intubation was due to a combination of effects of the inducing agent earlier and the effect or passing end tracheal tube later. ${ }^{[10]}$

Abou-Madi (1977) reported that a dose of $0.75 \mathrm{mg} / \mathrm{kg}$ of intravenous lignocaine was insufficient as antiarrhythmic while a dose of $1.5 \mathrm{mg} / \mathrm{kg}$ of i.v. lignocaine afforded complete protection against arrhythmias and also tachycardia, is similar to our finding of decreased tachycardia and absence of arrhythmias in group B.

The absence of arrhythmis and S.T segment changes in our study could be because of adequate level of anaesthesia, absence of hypoxia or hyupercarbia and rapid intubation and cardio protective antiarrythmic effect of both drugs.

The hypertensive patients in group B and in Group C did not differ from the other in a significant manner.

It was concluded in the study of attenuation of haemodynamics at larygoscopy and endotracheal intubation, that Esmolol hydrochloride was effective in attenuating the 
0

presser responses observed from the data. In the group where iv lingocaine was used, duration of tachycardia, hypertension and arrhythmias was reduced when compared to control. Intravenous Esmolol (500 $\mathrm{mcg} / \mathrm{kg}$ ) was found to be better in reducing the magnitude and duration of presser response.

\section{Conclusion}

In conclusion cardiovascular reaction of laryngoscopy and endotracheal intubation are potentially harmful and methods to obviate these, have been sought, particularly in critically ill patients. IV Esmolol was found to be the best, in attenuating the magnitude and duration of the presser response. IV lignocaine was found to be less effective in diminising magnitude and duration of the presser response when compared to IV esmolol.

\section{References}

1. Forbes AM, Dally FG. Acute hypertension during induction of anaesthesia and endotracheal intubation in normotensive man. $\mathrm{Br} \mathrm{J}$ Anaesth. 1970;42:618-24.

2. King BD, Harris LC, Jr, Greifenstein FE, Elder JD, Jr, Dripps RD Reflex circulatory responses to direct laryngoscopy and tracheal intubation performed during general anesthesia. Anesthesiology. 1951;12:556-66.

3. Low JM, Harvey JT, Prys-Roberts C, Dagnino J. Studies of anaesthesia in relation to hypertension. VII: Adrenergic responses to laryngoscopy. Br J Anaesth. 1986;58:471-7.

4. Prys-Roberts C, Foëx P, Biro GP, Roberts JG. Studies of anaesthesia in relation to hypertension. V. Adrenergic beta-receptor blockade. Br J Anaesth. 1973;45:671-81.

5. Yukioka H, Yoshimoto N, Nishimura K, Fujimori M. Intravenous lidocaine as a suppressant of coughing during tracheal intubation. Anesth Analg. 1985;64:1189-92.

6. Laurito CE, Baughman VL, Becker GL, Polek WV, Riegler FX, VadeBoncouer TR. Effects of aerosolized and/or intravenous lidocaine on hemodynamic responses to laryngoscopy and intubation in outpatients. Anesth Analg. 1988;67:389-92.

7. Feng CK, Chan $\mathrm{KH}$, Liu KN, Or CH, Lee TY. A comparison of lidocaine, fentanyl, and esmolol for attenuation of cardiovascular response to laryngoscopy and tracheal intubation. Acta Anaesthesiol Sin. 1996:34:61-7.

8. Ramanathan J, Sibai BM, Mabie WC, Chauhan D, Ruiz AG. The use of labetalol for attenuation of the hypertensive response to endotracheal intubation in preeclampsia. Am J Obstet Gynecol. 1988:159:650-4.

9. Inada E, Cullen DJ, Nemeskal AR, Teplick R. Effect of labetalol or lidocaine on the hemodynamic response to intubation: A controlled randomized double-blind study. J Clin Anesth. 1989;1:207-13.

10. Chung KS, Sinatra RS, Chung JH. The effect of an intermediate dose of labetalol on heart rate and blood pressure responses to laryngoscopy and intubation. J Clin Anesth. 1992;4:11-5.

Copyright: () the author(s), publisher. Academia Anesthesiologica International is an Official Publication of "Society for Health Care \& Research Development". It is an open-access article distributed under the terms of the Creative Commons Attribution Non-Commercial License, which permits unrestricted non-commercial use, distribution, and reproduction in any medium, provided the original work is properly cited.

How to cite this article: Baig MA. Comparative Study of Attenuation of effects of Intubation on Blood Pressure Using IV Xylocard and IV Beta Blocker (Esmolol). Acad. Anesthesiol. Int. 2019;4(2):8-12.

DOI: dx.doi.org/10.21276/aan.2019.4.2.3

Source of Support: Nil, Conflict of Interest: None declared. 